\title{
Evaluation of wood volume in young eucalyptus trees with and without irrigation ${ }^{1}$
}

\author{
Adriano da S. Lopes ${ }^{2}$, Marcos V. Folegatti ${ }^{3}$, Gabriel Q. de Oliveira ${ }^{4}$, \\ Eder D. Fanaya Júnior ${ }^{5}$ Isabela B. Belchior ${ }^{6} \&$ Kelvin R. M. Brito \\ ${ }^{1}$ Post-doctoral study of the first author with financial resources from the Casadinho/PROCAD-CNPq, Universidade de São Paulo/Esalq \\ ${ }^{2}$ UEMS, Aquidauana, MS. E-mail: lopes@uems.br (Author correspondent) \\ ${ }^{3}$ ESALQ/USP, Piracicaba, SP. E-mail: mvfolega@usp.br \\ ${ }^{4}$ UFGD, Dourados, MS. E-mail: gabrielqo@hotmail.com. Bolsista CNPq \\ ${ }^{5}$ ESALQ/USP, Piracicaba, SP. E-mail: junior_edf21@hotmail.com \\ ${ }^{6}$ UEMS, Aquidauana, MS. E-mail: isabela bbelchior@hotmail.com. Bolsista PIBIC/UEMS \\ ${ }^{7}$ UEMS, Aquidauana, MS. E-mail: kelvin_rosalvo@hotmail.com. Bolsista PETRO/UEMS
}

\section{Key words:}

Eucalyptus spp.

volume equations

drip irrigation

micro-spray irrigation

\begin{abstract}
A B S T R A C T
Irrigation management has mostly been performed without criteria and, studies in relation to field-irrigated eucalyptus development are scarce. The aim of this study was to evaluate wood volume equations based on stem (trunk) diameter of two eucalyptus hybrids in initial development, with and without irrigation. The experiment was set up in Aquidauana, State of Mato Grosso do Sul, Brazil, from April, 2011 to March, 2012, with the eucalyptus hybrids, Eucalyptus grandis $\mathrm{x}$ Eucalyptus camaldulensis (Grancam) and Eucalyptus urophylla $\mathrm{x}$ Eucalyptus grandis (Urograndis). Evaluations were performed during the first year of crop development in which five mathematical models were tested for estimation of wood volume (Berkhout; Koperzik \& Gehrhardt; Exponential; Brenac; Hohenald \& Krenn). The best models for estimation of wood volume of young plants are Brenac, Exponential and Hohenald \& Krenn. The Brenac equation shows highest precision for estimating wood volume as a function of diameter at $5 \mathrm{~cm}$ height from the ground, with precision greater than $99 \%$ for plants up to 12 months of age, regardless of the use of irrigation.
\end{abstract}

Palavras-chave:

Eucalyptus spp.

equações de volume

gotejamento

microaspersão

\section{Avaliação do volume de madeira em árvores jovens de eucalipto, com e sem irrigação}

\begin{abstract}
R E S U M O
$\mathrm{Na}$ maioria das vezes, o manejo da irrigação tem sido realizado sem critérios e ainda são escassos os estudos em relação ao desenvolvimento de eucalipto irrigado em campo. O objetivo deste trabalho foi avaliar equações de volume de madeira com base no diâmetro do caule de dois híbridos de eucalipto em desenvolvimento inicial, sob irrigação e sem irrigação. O experimento foi instalado em Aquidauana, MS, no período de abril de 2011 a março de 2012, com os híbridos de eucalipto Eucalyptus grandis x Eucalyptus camaldulensis (Grancam) and Eucalyptus urophylla $\mathrm{x}$ Eucalyptus grandis (Urograndis), irrigados por gotejamento, microaspersão e também testemunha sem irrigação. As avaliações foram realizadas durante o primeiro ano de desenvolvimento da cultura quando foram testados cinco modelos matemáticos para estimativa de volume de madeira (Berkhout; Koperzik e Gehrhardt; Exponencial; Brenac; Hohenald e Krenn). Os melhores modelos de estimativa do volume de madeira de plantas jovens são os de Brenac, Exponencial e Holhenald e Krenn. A equação de Brenac apresenta maior precisão para estimar o volume de madeira em função do diâmetro a $5 \mathrm{~cm}$ de altura do solo com precisão acima de $99 \%$ para as plantas até 12 meses de idade, independente do uso da irrigação.
\end{abstract}

\section{INTRODUCTION}

According to Azevedo et al. (2011), forest plantations should be considered as a manner of helping to reduce the actions of impact caused on natural forests, because they can be sources of raw material for forest industries, as well as having an important ecological role in relation to atmospheric carbon sequestration, contributing to minimization of the greenhouse effect.

To meet world demand for paper, the cellulose industry has achieved expressive increases in production, which means there is raw material for increasing demand (Arruda et al., 2011).

Silva et al. (2011) highlighted that normally forest plantations are found in ecosystems sensitive to human disturbances because of sloped terrain, soils with low natural fertility and degraded older agricultural areas. Another factor which is very important for current forest plantations and for future forecasts is knowledge of the local climate (Rody et al., 2012). Baesso et al. (2010) have affirmed that thanks to the climate of Brazil and 
advances made in research and forest technology, eucalyptus may be harvested in a period of 5 to 7 years, when it comes to pulp production.

According to Carneiro et al. (2008), reforestation with eucalyptus trees is still a controversial matter in respect to water consumption and its relation to increase of the productivity, showing that the interactions that occur between the environmental conditions and gas exchanges in the tree canopy is essential for the determination of the quantity of water transpired. Stape et al. (2004) observed that the productivity of the Eucalyptus urophylla $\mathrm{x}$ Eucalyptus grandis (Urograndis) eucalyptus hybrid may be increased with the use of irrigation, leading to a gain of $22.4 \mathrm{Mg} \mathrm{ha}^{-1}$ using only $15 \%$ more water in comparison to non-irrigated areas, indicating water use efficiency of around $32 \%$.

According to Hubbard et al. (2010), the expansion rate of eucalyptus plantations in Brazil is quite accelerated, with the need for more information on the behavior of these plantations, especially in regard to water use, which varies according to intended forest productivity and intensity of management.

Wood volume constitutes one of the most important pieces of information for knowledge of forest potential available in a region, and individual volume provides a starting point for evaluation of the wood content of forest stands (Machado et al., 2002). The volumetric potential of a forest is usually estimated through the use of forest inventory techniques, and the best way of determining tree volume is through the use of the technique called "Stand Volume Equations", estimations based on diameter (Barros \& Silva Júnior, 2009).

There are various mathematical models for estimation of this volume and, in most cases, these volumetric models have been fitted in an approximate way by the ordinary least square method and non-linear least square method, using the Levenberg-Marquardt and Gauss-Newton algorithms (Silva et al., 2009). Thus, it is necessary to verify the precision of the most efficient models by means of adequate statistics, identifying which is most recommended for each species and location (Thomas et al., 2006).

Given these aspects, the aim of this study was to evaluate mathematical models for estimating wood volume based on tree stem (trunk) diameter in two eucalyptus hybrids in initial development under irrigated and non-irrigated conditions.

\section{Material ANd Methods}

The study was conducted in the municipality of Aquidauana, State of Mato Grosso do Sul, Brazil, with geographic coordinates of $20^{\circ} 26^{\prime} 50^{\prime \prime}$ South, $55^{\circ} 40^{\prime} 14^{\prime \prime}$ West and a mean altitude of 207 $\mathrm{m}$. Climate in the region, according to the Köppen classification was described as Aw, defined as a tropical savanna climate with a rainy season in the summer and a dry season in the winter, and annual average rainfall of around $1200 \mathrm{~mm}$. Soil in the area, according to EMBRAPA (2009) is classified as Ultisol (Argissolo Vermelho-Amarelo distrófico).

Climatic data were obtained at the climatological station of the Instituto Nacional de Meteorologia (National Meteorological Institute - INMET) set up in the municipality of Aquidauana, consisting of daily readings of rainfall, temperature (maximum, minimum and average), relative humidity of the air, overall solar radiation and wind speed, from April 20, 2011 to March 20, 2012 (Table 1).

The eucalyptus seedlings were planted in the field on April 20,2011 when they had an average height of $0.3 \mathrm{~m}$, spaced at $2.25 \times 4.00 \mathrm{~m}$

The experimental design was randomized blocks with split plots, using four blocks and two replications within each block. The treatments used in the plots corresponded to two irrigation systems (micro-spray and drip) and a control without irrigation. In the split-plots, the treatments consisted of the eucalyptus hybrids, namely Urograndis, clone I224 and Grancam, clone 1277. Each split-plot was composed of 10 plants $\left(90 \mathrm{~m}^{2}\right)$. The experimental area was composed of 3 ha, with 1 ha for each treatment of the plots (micro-sprinkler, drip and without irrigation). Stem (trunk) diameter at $5 \mathrm{~cm}$ from the ground and plant height were measured to check plant development throughout the 12-month period.

In the drip irrigated area, self-compensating drip emitters were used with a discharge/flow rate of $2.4 \mathrm{~L} \mathrm{~h}^{-1}$, spacing of 0.5 $\mathrm{m}$ between emitters and service pressure of $10 \mathrm{~m}$. In microspray irrigation, micro-sprinkler nozzles were used with unit

Table 1. Data of mean maximum, minimum and average temperature $\left(T_{\max }, T_{\min }\right.$ and $\left.T_{a}\right)$, relative air humidity (RH), overall solar radiation (Rs), wind speed at $2 \mathrm{~m}$ height $\left(\mathrm{WS}_{2}\right)$, and rainfall $(\mathrm{mm})$ during the period of study in Aquidauana, State of Mato Grosso do Sul, Brazil

\begin{tabular}{|c|c|c|c|c|c|c|c|}
\hline Months/year & $T_{\max }$ & $\begin{array}{l}\mathrm{T}_{\min } \\
{ }^{\circ} \mathrm{C}\end{array}$ & $\mathrm{T}_{\mathrm{a}}$ & $\begin{array}{c}\text { RH } \\
\%\end{array}$ & $\begin{array}{c}\text { Rs } \\
M J ~ m^{2} d^{-1}\end{array}$ & $\begin{array}{l}\mathrm{WS}_{2} \\
\mathrm{~m} \mathrm{~s}^{-1}\end{array}$ & $\begin{array}{c}\text { Rainfall } \\
\text { mm }\end{array}$ \\
\hline April/2011 & 29.3 & 17.2 & 23.3 & 71.6 & 16.7 & 0.7 & 52.0 \\
\hline May/2011 & 29.9 & 15.3 & 22.6 & 65.7 & 14.6 & 1.0 & 8.0 \\
\hline June/2011 & 29.1 & 14.1 & 21.6 & 65.6 & 16.1 & 1.2 & 16.4 \\
\hline July/2011 & 29.9 & 16.0 & 23.0 & 60.4 & 16.3 & 1.4 & 30.4 \\
\hline August/2011 & 33.7 & 18.0 & 25.8 & 53.4 & 20.1 & 1.5 & 37.2 \\
\hline September/2011 & 33.7 & 20.5 & 27.1 & 61.6 & 21.6 & 1.6 & 130.6 \\
\hline October/2011 & 33.6 & 20.9 & 27.3 & 62.8 & 23.8 & 1.7 & 140.4 \\
\hline November/2011 & 35.6 & 21.1 & 28.4 & 60.0 & 28.0 & 1.3 & 56.6 \\
\hline December/2011 & 34.9 & 22.6 & 28.7 & 67.0 & 21.9 & 1.4 & 90.8 \\
\hline January/2012 & 33.9 & 22.7 & 28.3 & 70.0 & 21.9 & 1.1 & 176.7 \\
\hline February/2012 & 33.1 & 22.0 & 27.6 & 72.0 & 24.1 & 0.8 & 134.1 \\
\hline March/2012 & 32.6 & 20.9 & 26.7 & 71.5 & 20.5 & 0.8 & 126.0 \\
\hline
\end{tabular}


flow/discharge of $48 \mathrm{~L} \mathrm{~h}^{-1}$, sprinkler radius of $1.5 \mathrm{~m}$ and service pressure of $40 \mathrm{~m}$ installed at $0.3 \mathrm{~m}$ from each plant.

Irrigation management was based on the reference evapotranspiration (ETo), using the Penman-Monteith equation (Allen et al., 1998). Crop evapotranspiration (ETc) was estimated according to Eq.1, followed by adaptations to localized irrigation calculated according to Eq. 2 (Bernardo et al., 2008).

$$
\mathrm{ETc}=\mathrm{ETokc}
$$

in which:

kc - crop coefficient $(0.70-0.82)$

$$
\mathrm{ETc}_{\mathrm{Loc}}=\mathrm{ETck}_{\mathrm{L}}
$$

in which:

$\mathrm{k}_{\mathrm{L}} \quad$ - correction factor, according to the localized irrigation method, estimated according to Eq. 3 (Keller \& Bliesner, 1990)

$$
\mathrm{k}_{\mathrm{L}}=0.1 \sqrt{\mathrm{PW}}
$$

in which:

PW - percentage of wetted area, calculated according to Bernardo et al. (2008)

The drip and micro-sprinkler irrigation systems resulted in PW values of $25.0 \%$ and $78.5 \%$, respectively. Readily available water for localized irrigation was used for calculation of irrigated water depth, and was calculated according to Eq. 4 .

$$
\mathrm{RAW}_{\mathrm{Loc}}=\left(\theta_{\mathrm{cc}}-\theta_{\mathrm{pmp}}\right) \mathrm{Z} " \mathrm{p} " \frac{\mathrm{PW}}{100}
$$

where:

$\mathrm{RAW}_{\mathrm{Loc}}$ - readily available water for localized irrigation

$\theta_{c c}$ - soil moisture at field capacity (matric potential of -10 $\left.\mathrm{kPa}, \mathrm{m}^{3} \mathrm{~m}^{-3}\right)$

$\theta_{\text {pmp }}$ - soil moisture at permanent wilting point (matric potential of $-1500 \mathrm{kPa}, \mathrm{m}^{3} \mathrm{~m}^{-3}$ )

Z - depth of root system, $970 \mathrm{~mm}$ (Reis et al., 2006)

"p" - soil water depletion factor for conifers (0.7), recommended by Allen et al. (1998)

The wood volume of each plant was calculated according to the area of section and length of the stem, as described in Müller et al. (2009). Five traditional mathematical models evaluated are presented below and were selected from the literature (Loetsch et al. 1973; Scolforo, 1997; Laar \& Akça, 2007). The models were fitted by the least squares method described by Draper \& Smith (1998) (Table 2).

These models were adjusted for each one of the eucalyptus hybrids and irrigation systems, with a view toward obtaining coefficients of regression, statistical parameters of comparison and analysis of residues. The precision of each model was evaluated individually with the following statistical analyses: adjusted coefficient of determination
Table 2. Models tested to estimate the volume of individual trees of two irrigated eucalyptus hybrids in initial development

\begin{tabular}{ll}
\hline \multicolumn{1}{c}{ Authors } & \multicolumn{1}{c}{ Models } \\
Berkhout & $Y=a+b \cdot S D+\varepsilon$ \\
Koperzik \& Gehrhardt & $Y=a+b \cdot S D^{2}+\varepsilon$ \\
Exponential & $Y=a \cdot \exp ^{b . S D}+\varepsilon$ \\
Brenac & $Y=a \cdot D^{b} c . S D+\varepsilon$ \\
Hohenald \& Krenn & $Y=a+b \cdot S D+c . S D^{2}+\varepsilon$ \\
\hline
\end{tabular}

a, $b$ and $c$ - Coefficients of the models; SD - Stem (trunk) diameter at $5 \mathrm{~cm}$ from ground level $(\mathrm{cm}) ; \varepsilon$ - random error

$\left(\mathrm{R}_{\mathrm{aj}}^{2}\right)$, standard error of the estimate $\left(\mathrm{S}_{\mathrm{yx}} \%\right)$ and graphic distribution of residues (\%).

The coefficient of determination $\left(\mathrm{R}^{2}\right)$ indicates the percentage of variation of the data observed around the mean value which is being explained by the fitted model. The $\mathrm{R}^{2}$ values were adjusted so that it would be possible to compare the values found since the degrees of freedom of the regression differ among the tested models. Eq. 5, used to obtain the values, is given by:

$$
\mathrm{R}_{\text {aj }}^{2}=1-\left(\frac{\mathrm{n}-\mathrm{i}}{\mathrm{n}-\mathrm{p}}\right) 1-\mathrm{R}^{2}
$$

in which:

$\mathrm{R}^{2}{ }_{\mathrm{aj}}$ - adjusted coefficient of determination

$\mathrm{i}^{\text {aj }}$ - equal to 1 if the model includes the intercept or 0 , if the model does not include "a"

n - number of data observed

p - number of parameters of the model (Ferreira, 2009)

The standard error of the estimate (Eq. 6) indicates the precision of the adjustment of a mathematical model. This criterion indicates how much the model errs, in relative terms, on average, upon estimating the dependent variable (Machado et al., 2008).

$$
S_{y x}=\sqrt{\frac{\sum_{i=0}^{n}\left(v_{i}-\bar{v}_{i}\right)^{2}}{(n-p)}}
$$

where:

$$
\begin{array}{ll}
S_{y x} & \text { - standard error of the estimate, } \% \\
\text { vi } & \text { - volume observed, } \mathrm{dm}^{3} \\
\bar{v}_{i} & \text { - volume estimated by the models, } \mathrm{dm}^{3} \\
n & \text { - number of data observed } \\
\mathrm{p} & \text { - number of parameters of the model }
\end{array}
$$

According to Draper \& Smith (1998), the use of residues in the relative form (percentage), according to the estimated dependent variable, is the most adequate in order to have a better idea of the dimension of the under- and overestimates of the real value and compare the diverse adjusted models. As graphic evaluation is subjective, it should be used together with the previously cited statistics. In a complementary way, for comparison of mean values, the Tukey's test $(\mathrm{p}<0.05)$ was used. 


\section{Results AND Discussion}

Throughout 12 months, it was seen that the irrigated treatments had an observed volume greater than the treatment without irrigation, and as of the sixth and seventh months, the difference between volumes showed a great discrepancy (Figure 1). It may be seen that the Brenac and Hohenald \& Krenn models always remained near the line of the observed volume, which shows, in a preliminary way, good precision. For the Berkhout model, in all the evaluated situations, it was seen that its use becomes necessary only as of the sixth or seventh month because in the previous months its estimate is negative. Soon after this period, it may be observed that the line of development draws away from the observed volume and from the Brenac and Hohenald \& Krenn models.

For the Urograndis hybrid without irrigation, good precision was observed for all the analysed models. This precision is related to the low wood volume found in this treatment since, even at 12 months, its volume was less than $1.00 \mathrm{dm}^{3}$ (Figure 1).

At 12 months of age, the percentage difference in wood volume of the Grancam hybrid between the irrigated and nonirrigated treatments was approximately $141.9 \%$ more for the irrigated condition. For the Urograndis hybrid, this difference was even greater, around $369.2 \%$. When the percentage difference between the Grancam and Urograndis hybrids without irrigation is compared, the value is $205.8 \%$; i.e., the Urograndis hybrid in the first year of growth appears to be more sensitive to lack of water (Figure 1).

After fitting of the equations, analysis of the parameters of the tested models was carried out, selecting those that presented the best performances in the estimation of wood volume for young eucalyptus plants, both for hybrids and for irrigation. The adjusted coefficient of determination, the standard error of the estimate, as well as the coefficients of regression for the volumetric models with and without irrigation are shown in Table 3.

In general, the Brenac model was the best for all the analysed situations, which showed a fit with the data greater than $99 \%\left(\mathrm{R}_{\mathrm{aj}}^{2}\right)$ and with the lowest standard errors of estimate. Nevertheless, upon evaluating the behavior of the distributions of residues, it is seen that there was an increase in variation as the plants acquired greater volume (Figures 2 and 3 ).

The Hohenald \& Krenn model also showed excellent results in the volume estimate of plants up to 12 months, with precision above $99 \%$ when used to estimate the volume of the Grancam hybrid with drip and micro-sprinkler irrigation and the Urograndis hybrid with micro-sprinkler irrigation.

In eucalyptus stands with various diameter classes and standard forest management, the Koperzik \& Gehrhardt and Hohenald \& Krenn models obtained values of $\mathrm{R}_{\mathrm{aj}}{ }_{\mathrm{aj}}$ around 0.75 and $\mathrm{S}_{\mathrm{yx}}$ of about $30 \%$. Azevedo et al. (2011) observed for the same models with the variable diameter, that there was less agreement when compared to the models that use diameter and height in their variable. According to Rolim et al. (2006), the simple entry forest models, such as Kopezki \& Gehrhardt and Hohenald \& Krenn are biased, which may explain the low values of $\mathrm{R}^{2}$ and the high values of $\mathrm{S}_{\mathrm{yx}}$. Nevertheless, the determination of the tree height is a laborious operation and subject to error (Couto \& Bastos, 1987); therefore, evaluation of the precision of this type of model which uses only the
A1.

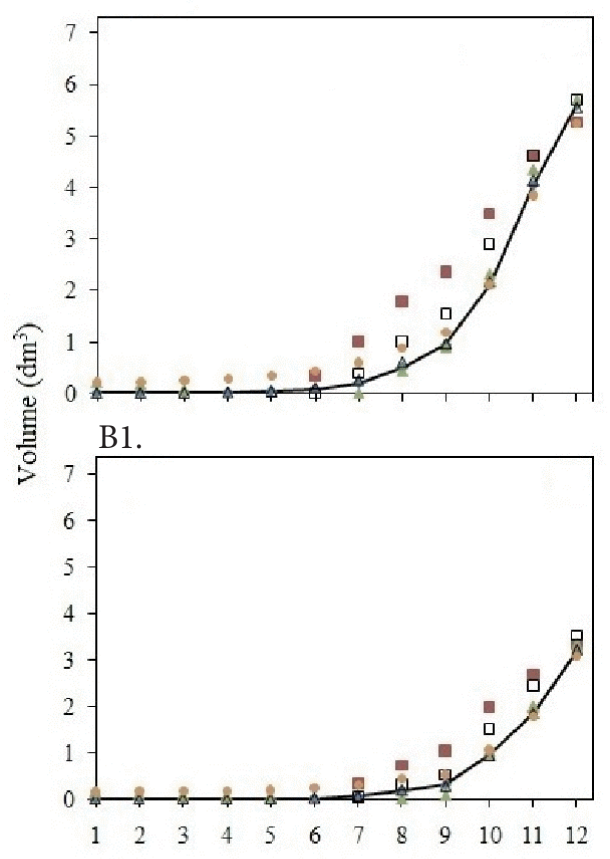

A2.

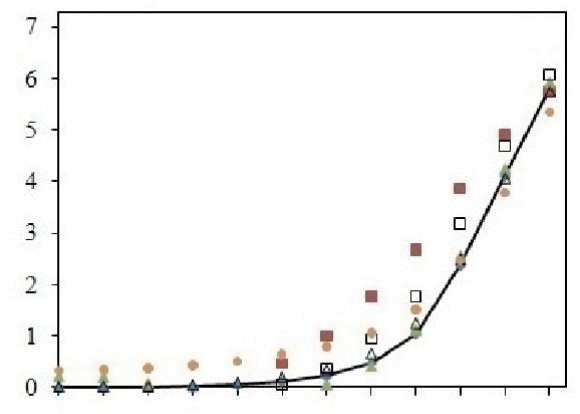

B2.

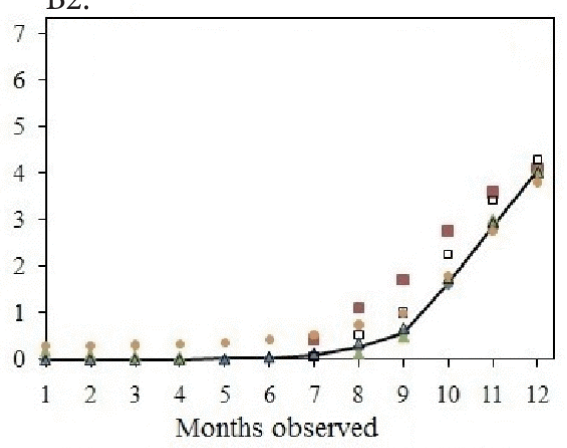

A3.

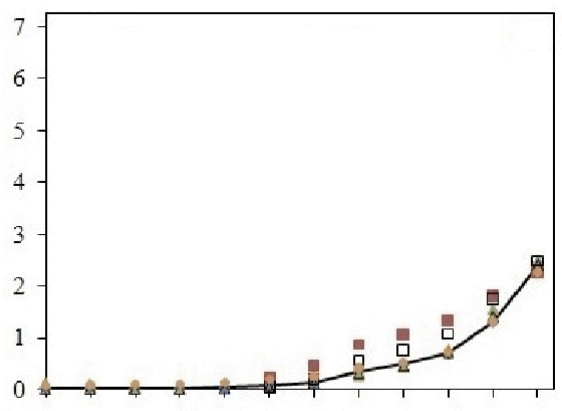

B3.

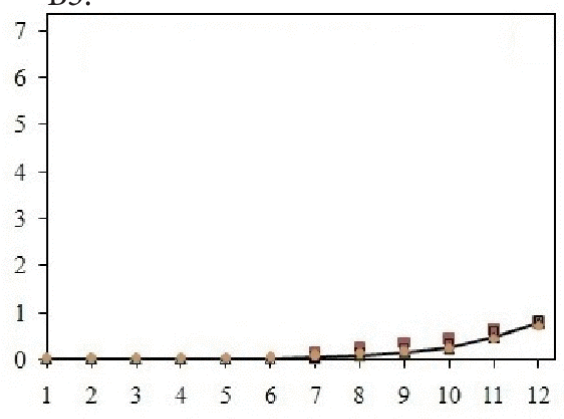

\section{Observed Berkhout $\square$ Koperzik\& Gehrhardt * Exponential $\Delta$ Brenac 4 Hohenald \& Krenn}

Figure 1. Behavior of the average monthly volume of wood per plant of the eucalyptus hybrids Grancam (A) and Urograndis (B), drip irrigated (1), micro-sprinklers (2) and without irrigation (3) 
Table 3. Estimates of the parameters of the adjusted equations, coefficient of determination and standard error $\left(\mathrm{S}_{\mathrm{yx}}\right)$ for volume $\left(\mathrm{dm}^{3}\right)$ of two irrigated eucalyptus hybrids in initial development

\begin{tabular}{|c|c|c|c|c|c|c|}
\hline \multirow{2}{*}{ Irrigation } & \multirow{2}{*}{ Models } & \multicolumn{4}{|c|}{ Coefficients } & \multirow{2}{*}{$\begin{array}{l}S_{y x} \\
(\%)\end{array}$} \\
\hline & & $a$ & b & C & $R_{\text {aj }}^{2}$ & \\
\hline \multicolumn{7}{|c|}{ Grancam hybrid } \\
\hline \multirow{6}{*}{ Drip } & Berkhout & -1.5361 & 1.2575 & - & 0.812 & 85.98 \\
\hline & $\begin{array}{l}\text { Koperzik \& } \\
\text { Gehrhardt }\end{array}$ & -0.4737 & 0.2085 & - & 0.958 & 39.74 \\
\hline & Exponential & 0.1709 & 0.6188 & - & 0.984 & 20.49 \\
\hline & Brenac & -0.3420 & 2.1185 & -0.0804 & 40.998 & 10.85 \\
\hline & Hohenald \& Krenn & 0.5837 & -1.0262 & 0.3601 & 10.993 & 16.60 \\
\hline & Berkhout & -1.8261 & 1.3982 & - & 0.794 & 99.15 \\
\hline \multirow{4}{*}{ Micro-sprinkler } & $\begin{array}{l}\text { Koperzik \& } \\
\text { Gehrhardt }\end{array}$ & -0.5672 & 0.2193 & - & 0.957 & 45.30 \\
\hline & Exponential & 0.2603 & 0.5330 & - & 0.969 & 21.75 \\
\hline & Brenac & -0.6680 & 1.9458 & -0.0542 & 20.996 & 12.61 \\
\hline & Hohenald \& Krenn & 0.6118 & -1.0580 & 0.3643 & 30.994 & 18.47 \\
\hline \multirow{5}{*}{$\begin{array}{l}\text { Without } \\
\text { irrigation }\end{array}$} & Berkhout & -0.7622 & 0.7168 & - & 0.764 & 36.01 \\
\hline & $\begin{array}{l}\text { Koperzik \& } \\
\text { Gehrhardt }\end{array}$ & -0.2561 & 0.1524 & - & 0.927 & 19.58 \\
\hline & Exponential & 0.0554 & 0.8593 & - & 0.986 & 6.87 \\
\hline & Brenac & -0.0581 & $2.4799-$ & -0.2611 & 10.993 & 6.30 \\
\hline & Hohenald \& Krenn & 0.4027 & -0.7590 & 0.2942 & & 11.22 \\
\hline \multirow{7}{*}{ Drip } & Urogr & andis hybr & & & & \\
\hline & Berkhout & -1.0781 & 1.0116 & - & 0.733 & 68.98 \\
\hline & $\begin{array}{l}\text { Koperzik \& } \\
\text { Gehrhardt }\end{array}$ & -0.3515 & 0.1912 & - & 0.929 & 35.54 \\
\hline & Exponential & 0.1251 & 0.6664 & - & 0.984 & 13.48 \\
\hline & Brenac & -0.1294 & 2.2728 & -0.1591 & 10.999 & 4.09 \\
\hline & Hohenald \& Krenn & 0.5420 & -0.9935 & 0.3512 & 20.987 & 15.71 \\
\hline & Berkhout & -1.2976 & 1.1219 & - & 0.768 & 86.27 \\
\hline \multirow{4}{*}{ Micro-sprinkler } & $\begin{array}{l}\text { Koperzik \& } \\
\text { Gehrhardt }\end{array}$ & -0.4015 & 0.1911 & - & 0.953 & 39.51 \\
\hline & Exponential & 0.2246 & 0.5400 & - & 0.963 & 21.88 \\
\hline & Brenac & -0.3212 & $1.9090-$ & -0.1102 & 20.996 & 9.25 \\
\hline & Hohenald \& Krenn & 0.4912 & -0.8931 & 0.3219 & 90.994 & 14.47 \\
\hline \multirow{5}{*}{$\begin{array}{l}\text { Without } \\
\text { irrigation }\end{array}$} & Berkhout & -0.3066 & 0.3880 & - & 0.778 & 12.84 \\
\hline & $\begin{array}{l}\text { Koperzik \& } \\
\text { Gehrhardt }\end{array}$ & -0.0920 & 0.1076 & - & 0.942 & 6.67 \\
\hline & Exponential & 0.0268 & 1.0709 & - & 0.984 & 1.89 \\
\hline & Brenac & -0.0357 & $2.2474-$ & & 30.997 & 1.85 \\
\hline & Hohenald \& Krenn & 0.1509 & -0.3691 & 0.1975 & 50.990 & 3.48 \\
\hline
\end{tabular}

diameter is relevant as it represents reduction in time and cost of forest inventory operations. In light of this, the importance of choosing the best models to estimate biomass according to the used management is seen, since not all the models show the same precision.

The coefficients of adjustment for the Berkhout model showed the lowest precision readings, indicating that the increase in volume does not behave in a linear manner for the Grancam and Urograndis hybrids with or without irrigation (Table 3). The low standard error of estimate (12.8\%) for this model in the Urograndis hybrid without irrigation (Table 3) is due to the low wood volume found in this hybrid throughout its development in 12 months.

It was possible to note that there is an inconsistency in the distribution of the points on both sides of the zero line (regression line), showing that there is a homogeneity in the variation between the real data and the estimates for the Berkhout model; this fact suggests that the wood volume does
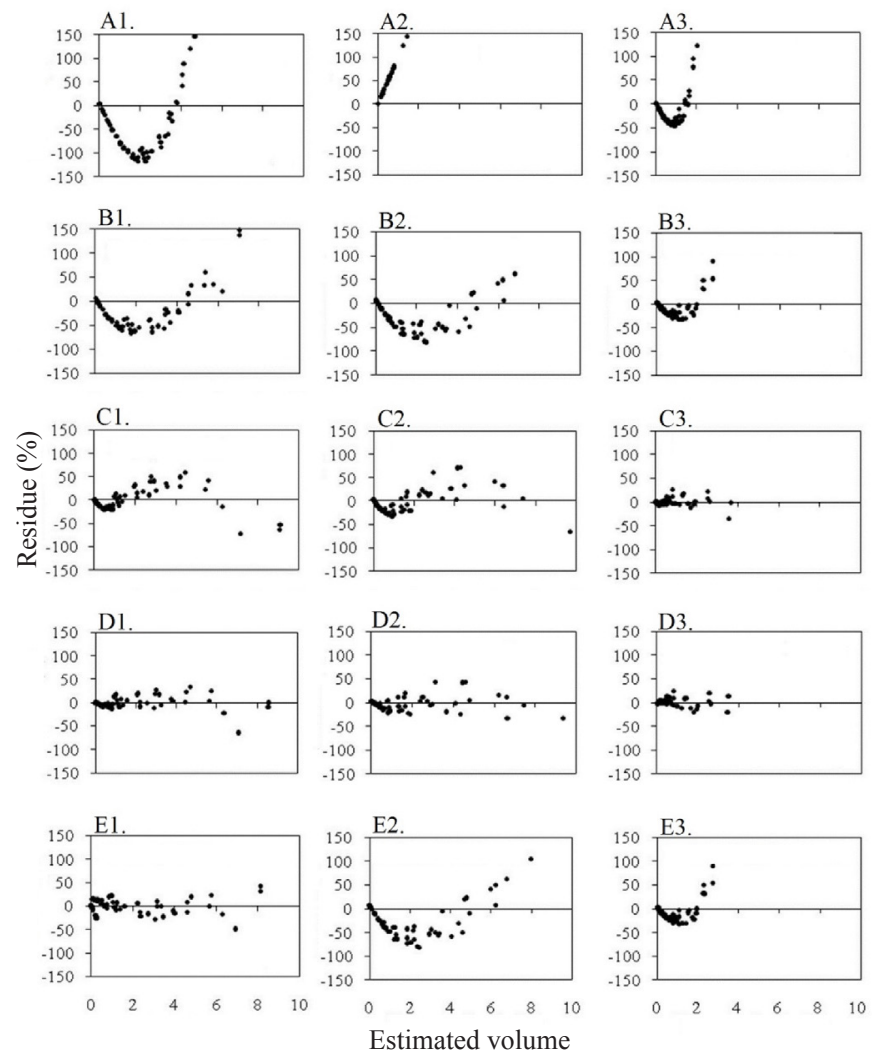

A, B, C, D and E correspond respectively to volume model of wood Berkhout, Koperzik \& Gehrhardt, Exponential, Brenac and Hohenald \& Krenn. Number 1, 2 and 3 correspond to drip irrigation, micro-sprinkler and without irrigation, respectively

Figure 2. Residues according to volume estimated for the volumetric models of the Grancam eucalyptus hybrid

not fit this model, and it is not recommended for future estimates (Figures 2 and 3).

The residue graph is highly useful in the choice of the model, a criterion which should not be observed in an isolated manner, but rather together with the $\mathrm{R}_{\mathrm{aj}}^{2}$ and $\mathrm{S}_{\mathrm{yx}}$ values so as to verify the behavior of the mathematical model throughout the regression line (Azevedo et al., 2011).

The data of the residue graphs generated by the Koperzik \& Gehrhardt model also suggest that, with the development of both hybrids, there are no adjustments to the quadratic model, for there is no randomness of the data observed with the increase in volume.

Notably, it may be seen that deviations from the zero residue for the Berkhout and Koperzik \& Gehrhardt models show a non-systematic pattern for the Grancam hybrid with drip and micro-sprinkler irrigation (Figure 2).

Graphic distribution of the residues showed trends in the Brenac, Exponential and Holhenald \& Krenn models for both hybrids in the irrigated environments, exhibiting, in general, a systematic pattern. They are negative for low values of estimated volume, alternating to positive and negative values of residues for higher volumes. This shows that the Brenac, Exponential and Holhenald and Krenn models are most recommended for estimating the volume of young eucalyptus plants in the two studied irrigation systems for both hybrids. 

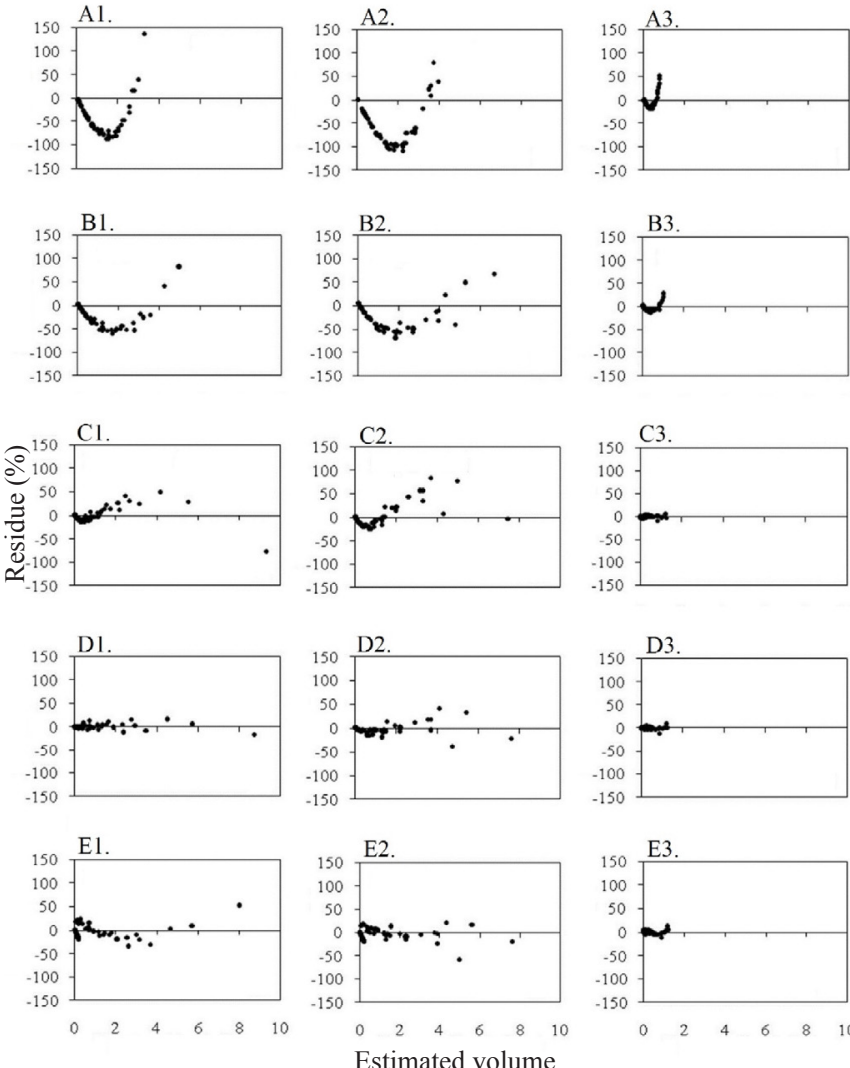

Estimated volume

A, B, C, D and E correspond respectively to volume model of wood Berkhout, Koperzik \& Gehrhardt, Exponential, Brenac and Hohenald \& Krenn. Number 1, 2 and 3 correspond to drip irrigation, micro-sprinkler and without irrigation, respectively

Figure 3. Residues according to volume estimated for the volumetric models of the Urograndis eucalyptus hybrid

\section{Conclusions}

1. The best models for estimation of the wood volume of young eucalyptus plants according to stem (trunk) diameter are Brenac, Exponential and Holhenald \& Krenn.

2. Regardless of the irrigation system used, the Brenac equation shows highest precision for estimating volume, according to diameter at $5 \mathrm{~cm}$ from the ground, with precision greater than $99 \%$ for eucalyptus (Grancam and Urograndis) up to 12 months of age.

3. Eucalyptus wood volume is 219 and $170 \%$ greater in areas with micro-sprinklers and drip irrigation in comparison to without irrigation.

\section{Literature Cited}

Allen, R. G.; Pereira, L. S.; Raes, D.; Smith, M. Pan evaporation method. In: Crop evapotranspiration: Guidelines for computing crop requirements. Rome: FAO, 1998. p.78-85. Irrigation and Drainage, 56

Arruda, O. G.; Tarsitano, M. A. A.; Alves, M. C.; Giácomo, R. G. Comparação de custos de implantação de eucalipto com resíduo celulósico em substituição ao fertilizante mineral. Revista Ceres, v.58, p.576-583, 2011.
Azevedo, T. L.; Mello, A. A.; Ferreira, R. A.; Sanquetta, C. R.; Nakajima, N. Y. Equações hipsométricas e volumétricas para um povoamento de Eucalyptus sp. localizado na FLONA do Ibura, Sergipe. Revista Brasileira de Ciências Agrárias, v.6, p.105-112, 2011.

Baesso, R. C. E.; Ribeiro, A. Silva, M. P. Impacto das mudanças climáticas na produtividade do eucalipto na região norte do Espírito Santo e sul da Bahia. Ciência Florestal, v.20, p.335-344, 2010.

Barros, P. L. C.; Silva Júnior, A. T. Equação de volume para árvores de uma floresta tropical densa no município de Anapu, oeste do estado do Pará, Amazônia oriental. Revista de Ciências Agrárias, v.51, p.115-126, 2009.

Bernardo, S.; Soares, A. A.; Mantovani, E. C. Manual de irrigação. 8.ed.Viçosa: UFV, 2008. 625p.

Carneiro, R. L. C.; Ribeiro, A.; Huaman, C. A. M.; Leite, F. P.; Sediyama, G. C.; Neves, J. C. L. Consumo de água em plantios de eucalipto: Parte 2 Modelagem da resistência estomática e estimativa da transpiração em tratamentos irrigados e não-irrigados. Revista Árvore, v.32, p.11-18, 2008.

Couto, H. T. Z.; Bastos, N. L. M. Modelos de equações de volume e relações hipsométricas para plantações de Eucalyptus no Estado de São Paulo. IPEF, v.37, p.33-44, 1987.

Draper, N.; Smith, H. Applied regression analysis. New York: John Wiley \& Sons, 1998. 736p.

EMBRAPA - Empresa Brasileira Brasileira de Pesquisa Agropecuária. Sistema brasileiro de classificação de solos. Rio de Janeiro: Centro Nacional de Pesquisa de Solos/ Embrapa Solos, 2009. 412p.

Ferreira, D. F. Estatística básica. Lavras: UFLA, 2.ed., 2009. 664p. Hubbard, R. M.; Stape, J.; Ryan, M. G.; Almeida, A. C.; Rojas, $J$. Effects of irrigation on water use and water use efficiency in two fast growing Eucalyptus plantations. Forest Ecology and Management, v.259, p.1714-1721, 2010.

Keller, J.; Bliesner, R. D. Sprinkle and trickle irrigation. New York: van Nostrand Reinold, 1990. 652p.

Laar, A.; Akça, A. Forest mensuration. Dordrecht: Springer. 2007. 383p.

Loetsch, F.; Zöhrer, F.; Haller, K. E. Forest inventory. München: BLV. 1973. 479p.

Machado, S. A.; Conceição, M. B.; Figueiredo, D. J. Modelagem do volume individual para diferentes idades e regimes de desbaste em plantações de Pinus oocarpa. Revista Ciências Exatas e Naturais, v.4, p.185-197, 2002.

Machado, S. A.; Nascimento, R. G. M.; Augustynczik, A. L. D.; Silva, L. C. R.; Figura, M. A.; Pereira, E. M.; Téo, S. J. Comportamento da relação hipsométrica de Araucaria angustifolia no capão da Engenharia Florestal da UFPR. Pesquisa Florestal Brasileira, v.56, p.5-16, 2008.

Müller, M. D.; Fernandes, E. N.; Castro, C. R. T.; Paciullo, D. S. C.; Alves, F. F. Estimativa de acumulo de biomassa e carbono e sistema agrossilvipastoril na zona da mata mineira. Pesquisa Florestal Brasileira, v.60, p.11-17, 2009. 
Reis, G. G.; Reis, M. G. F.; Fortan, I. C. I.; Monte, M. A.; Gomes, A. N.; Oliveira, C.H.R. Crescimento de raízes e da parte aérea de clones de híbridos de Eucalyptus grandis X Eucalyptus urophylla e de Eucalyptus camaldulensis X Eucalyptus spp submetidos a dois regimes de irrigação no campo. Revista Árvore, v.30, p.921-931, 2006.

Rody, Y. P.; Cecílio, R. A.; Pezzopane, J. E. M.; Ribeiro, A.; Almeida, A. Q. Influencia del cambio climático en los escenarios del futuro sobre plantaciones de Eucalipto. Revista Ciência Agronômica, v.43, p.470-477, 2012.

Rolim, S. G.; Couto, H. T. Z.; Jesus, R. M.; França, J. T. Modelos volumétricos para a Floresta Nacional do Tapirapé-Aquirí, Serra dos Carajás (PA). Acta Amazônica, v.36, p.107-114, 2006.

Scolforo, J.R.S. Técnica de regressão aplicada para estimar: Volume, biomassa, relação hipsométrica e múltiplos produtos da madeira. Lavras: UFLA, 1997. 292p.
Silva, M. A.; Silva, M. L. N.; Curi, N.; Avanzi, J. C.; Leite, F. P. Sistemas de manejo em plantios florestais de eucalipto e perdas de solo e água na região do Vale do Rio Doce, MG. Ciência Florestal, v.21, p.765-776, 2011.

Silva, M. L. M.; Binoti, D. H. B.; Gleriani, J. M.; leite, H. G. Ajuste do modelo de Schumacher e Hall e aplicação de redes neurais artificiais para estimar volume de árvores de eucalipto. Revista Árvore, v.33, p.1133-1139, 2009.

Stape, J. L.; Binkley, D.; Ryan, M. G.; Gomes, A. N. Water use, water limitation, and water use efficiency in a Eucalyptus plantation. Bosque, v.25, p.35-41, 2004.

Thomas, C.; Andrade, C. M.; Schneider, P. R.; Finger, C. A. J. Comparação de equações volumétricas ajustadas com dados de cubagem e análise de tronco. Ciência Florestal, v.16, p.319-327, 2006. 